\title{
A Colônia do Rio Uvá: Várias Histórias em Uma Só
}

The Rio Uvá Colony: Many Stories in a Single One

Sidney de Souza SILVA * Heloísa Augusta Brito de MELLO **

Resumo: Neste estudo, de natureza etnográfica, focalizamos recortes da história de um grupo de imigrantes de origem alemã que por volta de 1924 se instalou às margens do rio Uvá, a 50 quilômetros da Cidade de Goiás, antiga capital do Estado de Goiás. Com base nos conceitos de memória individual versus coletiva, buscamos (re)construir a trajetória desses imigrantes com o propósito de identificar os fatores que contribuíram para o deslocamento da língua alemã na comunidade. Os dados mostram que o alemão, única língua falada na comunidade à época da imigração, foi pouco a pouco sendo deslocada pelo português, passando a existir apenas na memória coletiva do grupo como uma língua herdada, um símbolo de etnicidade que une suas histórias em uma única - a história da Colônia do Rio Uvá.

Palavras-chave: Memória coletiva; Memória individual; Imigração.

Abstract: This ethnographic study presents the stories of a German immigrant group that in 1924 was settled near the River Uvá, distant $50 \mathrm{~km}$ of Cidade de Goiás, the former Capital of Goiás State. Memory concepts such as individual memory versus collective memory were used to (re)construct the story of these immigrants with the aim of identifying the main factors that caused the displacement of the German

* Mestre em Letras e Linguística pela Universidade Federal de Goiás (UFG). Docente do Instituto Federal Goiano - Campus Morrinhos. Contato: sydneysilva18@hotmail.com.

** Doutora em Linguística Aplicada pela Universidade Estadual de Campinas (Unicamp). Docente da Universidade Federal de Goiás - Faculdade de Letras. Contato: heloisabrito@brturbo.com.br. 
language in their community. Data shows that German, the only language spoke inside the community at that time, was gradually displaced by the Portuguese language. As a result, nowadays the German language assumes an important role in the group's collective memory for it is seen as a heritage language, a symbol of ethnicity that binds their stories into a single one - the story of the Rio Uvá Colony.

Key-words: Collective memory; Individual memory; Immigration.

\section{Introdução}

$\mathrm{Na}$ história brasileira, os imigrantes, ao lado dos indígenas, dos africanos e do colonizador português, tiveram um papel importante na constituição étnica e cultural do povo brasileiro. No período dos grandes movimentos imigratórios, o contingente europeu e asiático introduzido no Brasil entre 1886 e 1930 é avaliado em 5 milhões de pessoas, distribuídos entre 1,7 milhão de imigrantes portugueses, 1,6 milhão de italianos, 700 mil espanhóis, 250 mil alemães, $230 \mathrm{mil}$ japoneses e outros contingentes menores de etnias diversas (RIBEIRO, 2006 [1992]). Embora concentrados em maior número nas regiões sulinas, os imigrantes e seus remanescentes encontram-se espalhados por todo território brasileiro. Junto trouxeram suas línguas de origem, seus hábitos, seus costumes, sua cultura, imprimindo uma nova fisionomia à sociedade e à cultura nacional. Conquanto relevante na constituição da história e da cultura brasileira, os imigrantes não tiveram êxito na imposição de suas línguas, ficando a maioria delas confinadas em suas respectivas comunidades e, ainda assim, restritas a determinados domínios de uso. Desses processos imigratórios surgiram situações de contato linguístico que resultaram em mudanças nos usos e funções das línguas, levando a diferentes momentos de bilinguismo na comunidade e graus de competência de seus falantes, a exemplo da comunidade em tela neste estudo.

Segundo Bolognini e Payer (2005), os estudos linguísticos em contextos de imigração são importantes porque focalizam a diversidade das línguas introduzidas no Brasil pelos imigrantes, além de mostrarem que em diversos períodos históricos a imigração produziu mudanças no contexto sociolinguístico do Brasil, estremecendo, assim, a imagem da unidade da língua nacional brasileira, o português. 
Com o intuito de desvelar um desses contextos de imigração, focalizamos neste estudo recortes da história de um grupo de imigrantes de origem alemã que por volta de 1924 se instalou às margens do rio Uvá, a 50 quilômetros da Cidade de Goiás, antiga capital do Estado de Goiás. Com base nos conceitos de memória-hábito versus memórialembrança e de memória individual versus coletiva (POLLAK, 1989; BOSI, 1994; HALBWACHS, 2004), buscamos (re)construir a trajetória desses imigrantes com o propósito de identificar o lugar que a língua alemã ocupa hoje na comunidade, outrora falada em praticamente todos os domínios sociais bem como os fatores que contribuíram para o seu deslocamento na comunidade .

$\mathrm{O}$ artigo está dividido em três partes. Na primeira parte, apresentamos a comunidade que serviu de cenário para este estudo e traçamos os caminhos que nos permitiram gerar os dados; na segunda, discutimos os conceitos de memória - memória-hábito versus memórialembrança e memória individual versus memória coletiva - propostos por Bosi (1994), Halbwachs (2004) e Pollak (1992), entre outros. Por fim, na terceira parte apresentamos recortes das histórias de vida dos participantes com o intuito de estabelecer, a partir das memórias individual e coletiva do grupo, uma relação entre o contexto sóciohistórico e os fatores que contribuíram para o status atual da língua alemã na comunidade.

\section{A Colônia do Rio Uvá}

A Colônia do Rio Uvá era composta inicialmente por 97 famílias de imigrantes oriundas de diversas regiões da Alemanha, tais como a Renânia, a Pomerânia, o Marco de Brandeburgo e a Prússia Oriental. Motivados pelo agravamento da crise econômica que atingiu a Europa logo após a $1^{\text {a }}$ Guerra Mundial e pelas vantagens oferecidas pelo governo brasileiro aos imigrantes europeus naquela época, os alemães que aqui chegaram em 1924 esperavam encontrar em terras goianas melhores condições de vida em face da situação de empobrecimento em que se encontravam na Alemanha. Para esses alemães, a oferta do governo de Goiás parecia ser a opção ideal. Segundo Brito (1992), além de terras gratuitas, cerca de 10 a 50 hectares para cada casal de imigrantes, o governo do Estado prometia conceder ajuda para construção de moradias, aquisição de sementes e instrumentos 
destinados à lavoura, bem como assistência médica e alimentação. Com esta iniciativa, além de atender às necessidades dos imigrantes, as autoridades goianas esperavam dar início ao tão almejado projeto de colonização e ao mesmo tempo minimizar a dificuldade que a então Diretoria de Povoamento enfrentava para assentar em terras devolutas a grande quantidade de imigrantes que aguardava acomodação no Brasil.

Como veremos, esse cenário promissor logo se esvaneceu diante das inúmeras dificuldades. Após uma viagem exaustiva de navio da Europa até o Rio de Janeiro, seguida de trem até Goiás e de modo improvisado até a Cidade de Goiás, em alguns casos a pé e de carro de bois, os imigrantes receberam a notícia de que ainda não havia um local definido para a imediata instalação do grupo recém-chegado. Foram, então, alojados provisoriamente na Chácara do Areião e só algum tempo depois, o governo do Estado destinou uma região de terras devolutas às margens do rio Uvá para a implantação do núcleo colonial. Contudo, segundo Brito (1992), a concessão dos lotes em tal região não foi efetuada antes da demarcação oficial das terras, resultando na instalação dos imigrantes em ranchos provisórios e só após quatro meses, com a distribuição efetiva dos lotes, é que cada família pôde construir sua moradia em seu próprio terreno.

Além das dificuldades iniciais de assentamento, os alemães - em sua maioria, antigos operários da Renânia, ex-combatentes da Primeira Guerra e alguns poucos agricultores da Pomerânia, tiveram que aprender a lidar com trabalhos para os quais não estavam preparados: a demarcação dos lotes coloniais, o desbravamento de uma terra de matas fechadas, o confronto com animais selvagens, a construção de ranchos de pau-a-pique, o cultivo da terra sem, no entanto, disporem de técnicas e ferramentas adequadas para a realização dessas tarefas. A tudo isso se somava a alimentação escassa e diferente daquela com a qual estavam habituados, as condições climáticas com temperaturas pouco amenas e períodos intensos de chuva, entre outras situações adversas. Atualmente, a localidade é composta por pequenas propriedades rurais e está voltada para a pecuária e a agricultura de subsistência. A sua população é estimada em aproximadamente 300 pessoas, sendo que, dessas, apenas alguns são alemães ou seus descendentes, e os demais brasileiros que pouco a pouco foram se estabelecendo na região. 


\section{Os participantes}

O estudo contou com a participação de 12 indivíduos remanescentes da colonização e de seus descendentes, que gentilmente se dispuseram a nos narrar suas histórias acerca da formação da colônia e do contato entre as línguas e culturas alemã e brasileira no local. Utilizando a técnica da "bola de neve" (MARGOLIS, 1993 apud FREITAS, 2003), ${ }^{1}$ foram contatados 4 indivíduos da $1^{\text {a }}$ geração, nascidos na Alemanha e que vieram para o Brasil naquela época, e 8 indivíduos da $2^{\mathrm{a}}$ geração, filhos de alemães, mas nascidos já no Brasil. Para a caracterização dos participantes de acordo com suas gerações, nos baseamos no princípio de jus solis - princípio determinador da nacionalidade que leva em conta o local de nascimento do indivíduo (KEESING, 1972; BASTOS, 1999). Assim, em nosso estudo, consideramos como primeira geração todos os indivíduos que nasceram na Alemanha e vieram para o Brasil. Dessa forma, mesmo aqueles indivíduos que eram crianças no momento da migração são considerados nesse estudo como indivíduos da primeira geração. ${ }^{2} \mathrm{~A}$

${ }^{1}$ Essa técnica consiste em fazer uso da própria rede de parentes, amigos e conhecidos dos participantes na configuração do corpus. O principal procedimento é buscar as indicações feitas pelos primeiros participantes, que, na medida em que vão sendo entrevistados, passam a indicar outros possíveis participantes, que por sua vez, indicam outros mais e, assim, sucessivamente, até a dilatação ideal do número de indivíduos ligados à área de interesse.

${ }^{2} \mathrm{Em}$ geral, as crianças que acompanham seus pais nos movimentos migratórios podem ser consideradas como a segunda geração em relação aos adultos que participaram do mesmo processo migratório, quer estas tenham nascido no país de origem ou no país acolhedor. No entanto, em nosso estudo não tivemos acesso aos indivíduos que eram adultos durante o processo de migração, visto que todos já faleceram. Assim, preferimos caracterizar os participantes deste estudo de acordo com o princípio mencionado - jus solis - , pois consideramos que esta seria uma forma coerente de diferenciar as gerações e os indivíduos existentes, hoje, naquele contexto. Também ressaltamos que seguramente há diferenças no uso das línguas entre imigrantes adultos e crianças. No entanto, o uso que os imigrantes adultos faziam das línguas, de certa forma, perpassa a este estudo. Assim, a pesquisa está relacionada, sobretudo, ao uso das línguas por imigrantes alemães que eram crianças no momento da migração, pelos filhos daqueles que vieram adultos e ainda pelos filhos de alguns que vieram crianças. 
segunda geração é composta pelos filhos dos alemães (primeira geração) que nasceram no Brasil, e são considerados como terceira geração aqueles indivíduos que são filhos dos descendentes de alemães já nascidos nos Brasil.

\section{A orientação metodológica}

Considerando que o indivíduo é um ser social que não se desvincula do seu contexto social imediato, optamos por uma orientação metodológica que priorizasse as histórias de vida dos participantes na expectativa de poder registrar aspectos relevantes da sua sociedade tais como comportamentos culturais e linguísticos, valores e ideologias. Acreditávamos que dando voz aos participantes, sobretudo, às pessoas idosas que se valem de suas memórias para relatar suas experiências vividas, poderíamos reconstruir a trajetória da língua alemã na comunidade em termos de usos e funções.

Desse modo, seguindo os pressupostos metodológicos de Queiroz (1988), Thompson (1992) e Poirier, Clapier-Valladon e Raybaut (1999), demos início ao registro de dados por meio de entrevistas e conversas informais com os participantes da pesquisa, entre outros instrumentos, na expectativa de poder compreender os processos de manutenção, deslocamento ou perda da língua alemã na comunidade, bem como identificar os fatores que influenciaram esses processos. $\mathrm{O}$ trabalho com base em fontes orais mostra-se eficaz para investigar grupos minorizados, ${ }^{3}$ como os de imigrantes, visto que estes costumam preservar a sua própria tradição oral, por meio da qual é possível

${ }^{3}$ Geralmente, nas situações em que duas ou mais línguas estão em contato, o grupo que tem mais poder político, econômico e social usa esse poder, intencionalmente ou não, para estabelecer as normas de convívio social e de usos das línguas, colocando aqueles que têm menos poder em uma situação de desvantagem. Como resultado, a língua também acaba recebendo menor prestígio na sociedade e não raras vezes é eliminada, pois seus falantes decidem parar de usá-la para evitar qualquer tipo de estigma que possa ser por ela revelado. É por isso que atualmente muitos estudiosos têm dado preferência à expressão línguas minoriz̨adas ao invés de minoritárias. $\mathrm{O}$ termo minorizada coloca em evidência uma condição imposta e não intrínseca, além de não fazer projeções demográficas imprecisas acerca de determinadas realidades. 
estudar o seu passado e presente, especialmente quando se tratam de idosos, verdadeiros "guardiões do passado".

Logo percebemos que à medida que as histórias de vida eram narradas, passado e presente se sobrepunham a todo o momento, desvelando fatos registrados e evocados individual e coletivamente na memória do grupo. Com o intuito de compreender esse movimento entre passado e presente, recorremos aos conceitos de memória sustentados por (POLLAK, 1989; BOSI, 1994; HALBWACHS, 2004; entre outros). Esse é o tema da discussão na seção seguinte.

\section{Memória: um fenômeno de natureza complexa}

A memória é um fenômeno de natureza complexa, cujos estudos não se limitam a um único campo do saber. No campo da psicologia e da psicanálise, a memória é entendida como uma espécie de sumário interpretativo de nossas experiências passadas, que permite manipular e compreender o mundo à nossa volta, recriando-o por meio de ações da imaginação (BUENO, 2004), com a diferença de que, para a teoria psicanalítica, o mais importante nem sempre é o que pode ser lembrado, mas justamente o que se pode esquecer (CARVALHO, 2004). $\mathrm{Na}$ perspectiva das neurociências, a memória é interpretada como uma função mental biológica cujo papel central é o armazenamento e o processamento de informações no sistema nervoso humano. A psicolinguística, por sua vez, como uma área de estudo que se ocupa da organização e da percepção dos processos mentais envolvidos na aquisição, na produção e na compreensão da linguagem, também está ligada à memória no que diz respeito aos mecanismos de armazenamento e processamento de informações - memória de curtoprazo e memória de longo-prazo -; nesse sentido, o termo "memória" aparece como elemento constituinte e como condição para o entendimento do processamento da linguagem (CRUZ, 2004). No campo da antropologia, da história e da sociologia, a memória, grosso modo, é vista como uma construção de referenciais sobre o passado e o presente de diferentes grupos sociais ancorados nos costumes, nas tradições e intimamente associados a mudanças culturais. ${ }^{4}$

\footnotetext{
${ }^{4}$ Cf. httmp:/ / www.comciência.br/reportagens/memória. Memória é matéria prima do trabalho do historiador. Acesso em 21.07.2008.
} 
Este estudo coaduna-se com essa última perspectiva, sobretudo no que diz respeito à relação entre memória e grupo social. Nesse sentido, a partir de uma visão sociocultural, buscamos mostrar como a língua alemã outrora falada na comunidade foi pouco a pouco deslocada pelo português, passando a existir apenas na memória coletiva do grupo como uma língua herdada, mas não necessariamente em uso.

\subsection{A memória na perspectiva dos estudos socioculturais}

\subsubsection{Memória-hábito versus memória-lembrança}

Os estudos socioculturais distinguem memória-hábito de memória-lembrança. A primeira diz respeito à capacidade de o indivíduo guardar esquemas de comportamento apreendidos ao longo de sua existência e dos quais se vale automaticamente em suas ações sobre as coisas. É a memória dos mecanismos motores. A segunda refere-se às memórias independentes de quaisquer hábitos. São lembranças isoladas, singulares, que, segundo Bosi (1994, p. 48), constituem-se em "autênticas ressurreições do passado".

A memória-hábito é adquirida pelo esforço da atenção e pela repetição de comportamentos. Trata-se, portanto, de um exercício que, retomado até a fixação, transforma-se num hábito ou num serviço para a vida cotidiana. É graças a esse serviço desempenhado pela memória-hábito que o indivíduo sabe "de cor" os movimentos exigidos para comer segundo as regras da etiqueta, escrever à mão ou digitar um texto em um teclado, dirigir um automóvel ou andar de bicicleta, costurar, usar o computador e assim por diante. Nas palavras de Bosi (1994, p. 49), "a memória-hábito faz parte de todo o nosso adestramento cultural".

A memória-lembrança, por outro lado, é responsável pela capacidade do indivíduo de se lembrar de um momento único e irreversível em sua vida, cujo aparecimento na memória não tem caráter mecânico, mas sim evocativo. Bosi (1994, p. 49) ressalta que "a imagemlembrança [evocada pela memória] tem data certa: refere-se a uma situação definida, individualizada, ao passo que a memória-hábito já se incorporou às práticas do dia-a-dia". Ainda a respeito da faculdade de lembrar, Bosi (1994, p. 55) ressalta que: 
[...] lembrar não é reviver, mas refazer, reconstruir, repensar, com imagens e idéias de hoje, as experiências do passado. A memória não é sonho, é trabalho. [...] A lembrança é uma imagem construída pelos materiais que estão, agora, à nossa disposição, no conjunto das representações que povoam nossa consciência atual.

Assim, a narração da própria vida é, segundo o autor, o testemunho mais eloquente dos modos que o indivíduo possui para se lembrar, é a reconstrução dos fatos vividos individual ou coletivamente, é a expressão vívida da memória, ou melhor, é a própria memória.

A memória-lembrança é típica das pessoas idosas. Diferentemente do adulto ativo, para quem a vida "é vida prática e a memória é fuga, arte, lazer e contemplação", para a pessoa idosa lembrar é ocupar-se consciente e atentamente dos enquadres de seu próprio passado, da própria substância de sua vida. Assim, na condição de membros não mais ativos da sociedade, os idosos assumem a única função que lhes resta: a de lembrar, e passam a ser a memória da família, do grupo, da instituição, da sociedade (BOSI, 1994, p. 60). Nas palavras do autor, suas lembranças tornam-se "autênticas ressurreições do passado” (p. 48).

\subsubsection{Memória individual versus memória coletiva}

Outra discussão, ainda no plano da memória, diz respeito à distinção entre memória coletiva e memória individual, postulada por Maurice Halbwachs, pensador e sociólogo francês. Seu estudo sobre A memória coletiva, publicado postumamente em 1950, tornou-se um texto clássico sobre memória em âmbito social. O termo "memória coletiva" surgiu num período em que a memória era vista apenas no plano individual, como na literatura de Proust ou na psicanálise de Freud (DOUEK, 2003). Halbwachs também usa as expressões memória pessoal e memória autobiográfica para se referir à memória individual e memória social ou memória histórica para memória coletiva.

A memória autobiográfica, segundo Halbwachs (2004) é a memória dos fatos vividos, das coisas que lembramos e presenciamos. A memória histórica, ao contrário, extrapola o indivíduo, incorporando 
informações sobre o mundo à nossa volta. São fatos e coisas de que ainda nos lembramos, mas não necessariamente vivenciamos. Para o autor, a memória histórica perpassa completamente a memória autobiográfica na medida em que constitui uma espécie de enquadre social para o funcionamento da memória individual, criando um contexto social para que o indivíduo se recorde de fatos e coisas particulares do seu próprio passado.

Como aponta Douek (2003), Halbwachs se colocou contra o subjetivismo da memória, mostrando que a memória individual se apóia e se enraíza em uma memória coletiva, a memória dos diversos grupos nos quais vive o indivíduo: o grupo familiar, o grupo de trabalho, o grupo de amigos, o grupo religioso, o político, o artístico, o cultural e assim por diante. É, então, no seio dos diversos grupos sociais nos quais o indivíduo está imerso que se constrói sua memória, é com eles e neles que ela se estrutura.

Assim, na perspectiva de Halbwachs (2004), pode-se dizer que o indivíduo dispõe de duas espécies de memória, uma individual e outra coletiva, que se interpenetram. A memória individual pode se apoiar na memória coletiva, deslocando-se nela para confirmar parte de suas lembranças ou para cobrir suas lacunas, sem, no entanto, deixar de seguir o seu caminho. Já a memória coletiva envolve as memórias individuais, mas não se confunde com elas.

Segundo esse mesmo autor, para o indivíduo evocar seu próprio passado, ele precisa apelar com recorrência para as lembranças de outros, reportando-se a pontos de referência que existem fora de si mesmo e que são fixados na e pela sociedade circundante. Assim, o funcionamento da memória individual não se realiza sem passar pela memória coletiva, pelos fatos que se tornaram familiares a partir das palavras do grupo ao qual o indivíduo pertence, palco de inúmeros acontecimentos e dos quais se lembra, mas que não foram necessariamente por ele vividos, apenas conhecidos e reconhecidos nos depoimentos, nas narrativas, nas histórias de vida, na voz daqueles que participaram direta ou indiretamente. Esses acontecimentos ocupam um lugar na memória do grupo, e, quando o indivíduo evoca tais lembranças, é levado a confiar inteiramente na memória dos outros, que não completa ou fortalece a sua, mas que é a única fonte daquilo que ele quer repetir. 
Evocar o passado faz, pois, parte da vida do indivíduo e da coletividade. É uma operação, por natureza, múltipla, coletiva, plural, ao mesmo tempo em que é individualizada; é interior e exterior; e embora esteja aberta à dialética da lembrança e do esquecimento, a memória é sempre atual, visto que retém do passado somente aquilo que ainda está vivo ou é capaz de viver na consciência do grupo que a mantém (Douek, 2003).

Nessa perspectiva, o presente não se opõe ao passado, antes, sim, o presente se estende ao passado e vice-versa. Entre os dois, não há um corte abrupto, mas uma linha contínua, e isso é o que nos permite falar de um passado vivido, que é também vivo, sustentado pela consciência de um grupo que busca manter sua identidade, seus traços e peculiaridades através do tempo, como se pode observar na fala dos participantes deste estudo adiante.

Para Pollak (1992), a memória é um elemento constituinte do sentimento de identidade na medida em que é também um fator importante para o sentimento de continuidade e de coerência de uma pessoa ou de um grupo na (re)construção de sua história e imagem. Todavia, ressalta que a relação entre memória e identidade é tomada no seu sentido mais superficial, que é o sentido da imagem de si, para si e para os outros. Isto é, a imagem que uma pessoa adquire ao longo da vida e que se refere a ela própria, à imagem que constrói de si e que apresenta tanto aos outros como a si mesma. Assim, como resultado de uma operação conjunta dos acontecimentos e das interpretações do passado que o grupo quer preservar, a memória coletiva serve para reforçar sentimentos de pertencimento e definir fronteiras sociais entre coletividades de tamanhos diferentes, como partidos, sindicatos, igrejas, comunidades indígenas, grupos de imigrantes, regiões, clãs, famílias, nações etc. Desse modo, a referência ao passado serve para manter a coesão dos grupos e das instituições que compõem uma sociedade.

Entre os elementos que podem estruturar a memória do indivíduo e inseri-la na memória da coletividade estão o patrimônio arquitetônico e seu estilo, as paisagens, as datas e personagens históricas de cuja importância os indivíduos são incessantemente relembrados, as tradições e os costumes, o folclore e a música, e as tradições culinárias. A memória do indivíduo depende, então, do seu relacionamento com 
a família, com a classe social, com a escola, com a igreja, com a profissão, enfim, com os grupos de convívio e os grupos de referência peculiares a esse indivíduo (HALBWACHS, 2004; POLLAK, 1989; BOSI, 1994). Nessa perspectiva, a memória é, em parte, herdada e não se refere apenas à experiência vivida pela pessoa.

Segundo Douek (2003 p. 29):

A memória diz respeito à tradição, do latim, traditio, isto é, à ação de dar, de entregar, de ensinar, de transmitir, transmissão que ocorre, em geral, oralmente, de pai para filho, de geração em geração, transmissão de fatos, lendas, costumes, hábitos, práticas, valores, doutrinas, modos de agir e pensar, ensinamentos de determinado grupo social, e que assegura a identidade grupal, ou seja, a continuidade dos traços característicos próprios e fundamentais do grupo.

A afirmação de Douek sugere que a tradição aliada à memória coletiva cumpre a função de estender ao presente os traços peculiares a um grupo e que lhe imprimem uma identidade $x$ e não $y$. Tal posição está em consonância com Puillon ${ }^{5}$ (1991, apud WARNIER 2000) que afirma ser a tradição aquilo que persiste do passado no presente, aquilo que permanece na memória e é transmitido e aceito por aqueles que a recebem e que, por sua vez, continuam a transmiti-la ao longo das gerações. Nesse sentido, "há uma permanente interação entre o vivido e o aprendido, e o vivido e o transmitido. E essas constatações se aplicam a toda forma de memória, individual e coletiva, familiar, nacional e de pequenos grupos" (POLLAK, 1989, p. 8).

Contudo, Halbwachs (2004) afirma que a força e a duração da memória coletiva advêm do seu suporte em um conjunto de indivíduos, enquanto membros de um mesmo grupo. Ela é composta pela massa das lembranças comuns, apoiadas umas sobre as outras, mas aparecem com intensidade diferente para cada membro do grupo. Cada memória individual é, então, um ponto de vista sobre a memória

${ }^{5}$ PUILLON, J. Tradition. In: BONTE, P.; IZARD, M. Dictionnaire de l'etnologie et de l'anthropologie. Paris: PUF, 1991. p. 710-712. 
coletiva, que muda conforme o lugar ocupado pelo indivíduo no grupo, e este lugar pode mudar segundo as relações que o mesmo mantém com outros meios. Em outras palavras, nem todos vêem o instrumento comum da mesma maneira. Essa diversidade resulta, portanto, de uma combinação de influências que são, todas, de natureza social e dinâmica.

As características presentes nas histórias de vida de indivíduos pertencentes a um mesmo grupo sugerem que estas devem ser consideradas como instrumentos de reconstrução de sua identidade e não como simples relatos factuais, pois estes indicam acontecimentos que balizaram a existência do grupo (POLLAK, 1989). Nenhum grupo social, por mais estável e sólido que possa parecer, tem sua perenidade assegurada. No entanto, sua memória, pode sobreviver a seu desaparecimento.

Neste estudo, conforme procuramos mostrar a seguir, as histórias narradas pelos participantes de terceira geração fazem eco às histórias contadas pelos de primeira e segunda gerações como numa operação coletiva em que o vivido e o ouvido se sobrepõem para (re)construir fatos, costumes, práticas e valores que constituem a herança cultural do grupo. Entre os bens herdados, a língua é, sem dúvida, peça fundamental no processo de historização e de identificação grupal.

\section{A Colônia do Rio Uvá: várias histórias em uma só}

Os recortes de fala que apresentamos a seguir mostram parte das histórias vividas pelos participantes deste estudo que ficaram registradas em suas próprias memórias, muitas delas resgatadas de fatos ocorridos na coletividade. A memória, como já se mencionou anteriormente, é composta por lembranças vividas, únicas, e por lembranças de outros, compartilhadas. São, portanto, histórias vividas das quais os próprios indivíduos participaram ou ouviram dizer repetidamente em sua comunidade. É uma espécie de corrente contínua em que se interceptam pensamento e experiência, reunindo similitudes e analogias existentes entre os indivíduos de um mesmo grupo ou de um grupo para outro e que compõem o conjunto de seus traços identitários (HALBWACHS, 2004; DOUEK, 2003). Para Pollak (1989), a(s) identidade(s) que um indivíduo ou grupo de indivíduos constrói para si tem origem justamente nesta intersecção entre o vivido e o ouvido, isto é, entre a memória individual e a memória coletiva. 
Deste modo, a partir da interlocução entre as memórias individual e coletiva é que pudemos tomar conhecimento de fatos que remontam o processo imigratório que deu origem à Colônia do Rio Uvá e, assim, recompor a trajetória histórica dos participantes deste estudo. Tais fatos, vividos e recordados pelos participantes serviram de pistas para que pudéssemos compreender o papel e o lugar da língua alemã naquela comunidade à época da imigração e nos dias de hoje. As falas mostram uma trajetória de luta e perseverança, permeada por inúmeras adversidades, iniciada ainda na Alemanha - o empobrecimento dos alemães no local de origem, a viagem longa com pouco ou nenhum conforto, dificuldades com a nova língua e os novos costumes, a rudeza do destino final, a falta de apoio do Estado brasileiro, entre muitas outras.

Como mencionado anteriormente, para (re)construir esse percurso recorremos aos conceitos de memória-lembrança, memória coletiva e individual postulados por Pollak (1989), Bosi (1994), Halbwachs (2004), Douek (2003), entre outros. Semelhante à construção de um mosaico em que as peças vão pouco a pouco se encaixando, neste estudo fatos resgatados da memória dos participantes tais como os motivos da emigração, o local de origem, a viagem, os usos da língua etc. constituem peças únicas.

\subsection{A trajetória em direção ao Brasil}

\subsubsection{Os motivos da emigração}

Os recortes que se seguem descrevem as razões que levaram os alemães à Colônia do Rio Uvá. Desempregados e sem perspectivas em uma Europa falida, os imigrantes alemães buscaram melhores oportunidades no Brasil. As falas de Peter e Klaus mostram que a crise monetária instalada na Alemanha após a Primeira Guerra Mundial fazia com que a moeda alemã se desvalorizasse a cada hora, o que gerava um alto índice de inflação e resultava em constante empobrecimento da população. 
[Recorte 1] Peter: Os pais da gente vieram solteiros ainda; mamãe veio da Alemanha com onze anos quando saiu de lá, da Alemanha \# ela falava assim \# que lá, os últimos anos foram muito sofridos \#\# eles catavam batatinha na terra dos outros para poder viver, por causa da guerra naquela época. E a Alemanha estava muito fraca de poder e de guerra, aí quando eles vieram pra cá, eles vieram pobrezinhos, pobre, pobre mesmo \# quando ganhava um mamão de uma pessoa aqui, era a coisa melhor do mundo. (Entrevista A-12, 09/04/ 2006)

[Recorte 2] Klauss: Que dificuldade! \#\# A Alemanha estava uma pobreza - : se você fosse comprar uma caixa de fósforos, você falava: 'oh, me dá o dinheiro aí que eu vou trabalhar mais uma hora' e se ele fosse pagar uma hora depois, aquele dinheiro num dava mais para pagar a caixa de fósforos, então era uma situação muito desajeitada para quem viveu numa época anterior. (Entrevista A-22, 17/09/2006)

Além das dificuldades econômicas decorrentes da crise pósguerra, razões de ordem pessoal também atuaram como forças expulsivas em direção ao Brasil, a exemplo das famílias de Edith e Thora:

[Recorte 3] Edith: A minha família nem devia tá no meio \#\# porque o meu pai era bancário \# ele num sabia nada de lavoura $[\ldots]$ papai num queria ficar lá mais ... (Entrevista A-21, 02/08/2006)

[Recorte 4] Thora: O meu pai sempre sofreu de estômago, aí o médico disse pra ele pra trocar de clima, por isso que a gente já foi de Berlim pra fora de Berlim, pra trocar de clima \# mas num ficou melhor. Ele continuou trabalhando, aí bom, resolveu, resolveu vir de lá pra cá [...]. (Entrevista A-09, 07/04/2006) 
As vantagens oferecidas pelo governo do Estado de Goiás como parte de uma política de ocupação de terras devolutas também serviram de motivação em direção ao centro-oeste:

[Recorte 5] Thora: [...] aí lá em São Paulo ele perguntou... eu era menina..., a minha mãe que contou isso, ela que me contou \# nesse tempo eu tinha dez anos, aí ele perguntou pra onde que eles queriam ir, né? Meus pais queriam ir para Santa Catarina, mas esse alemão: 'vamos pra Goiás, lá em Goiás o governo também quer os alemães lá, estão doando terras'. (Entrevista coletiva A-10, 07/04/2006)

[Recorte 6] Edith: (...) então um tio meu queria ir com o meu pai pro México, só que houve uma tentativa de revolução no México \#\# meu pai já tinha pedido demissão no banco \# aí ele leu no jornal que estavam recrutando pessoas para colonizar aqui em Goiás, aí se juntou ao grupo.

Edith e Thora (recortes 3 e 4) evocam uma imagem-lembrança (BOSI, 1994) que tem data e locais certos, isto é, refere-se a uma situação definida, individualizada enquanto que Peter e Klauss (recortes 1 e 2) e Thora (recorte 5) se apóiam nos fatos que ouviram de seus pais e que de tão familiares passaram a ser conhecidos e reconhecidos em suas próprias vozes.

\subsubsection{Os locais de origem}

Em sua maioria, os imigrantes que vieram para Goiás eram oriundos das regiões da Renânia, da Pomerânia, de Berlim e da Prússia Oriental, como se observa nas falas de Judith, Heinz, Peter e Edith a seguir. Somavam à época da emigração um total de 120 famílias com aproximadamente 300 pessoas. Segundo consta, ao chegarem ao Centro de Imigração da Ilha das Flores, no Rio de Janeiro, os alemães foram divididos em dois grupos com destino à capital do Estado de Goiás. Um grupo seguiu primeiro; e o outro, alguns dias depois. 
[Recorte 7] Ent.: A senhora nasceu lá ou aqui?

Judith: Não, eu nasci lá.

Ent.: Em qual cidade da Alemanha?

Judith: Em Pomeronde.

Heinz: Em Pomeronde?

Judith: É, Pomeronde.

Heinz: Pomeronde fica perto da Polônia.

Judith: É. (...) a maioria era de cidades diferentes de lá. (Entrevista coletiva A-4, 22/01/2006)

[Recorte 8] Ent.: Ele veio de qual região da Alemanha?

Peter: De Berlim, ele veio de Berlim, mamãe já era de outro lugar. (Entrevista A-12, 09/04/2006)

[Recorte 9] Edith: [...] o meu pai morava numa região que era território alemão, mas ficava na Lituânia.

Ent.: $\mathrm{Na}$ Lituânia?

Edith: É, então aquela região era um território alemão [...] (Entrevista A_08,03/02/2006)

Elin, que à época da vinda para o Brasil estava com apenas três anos de idade, narra fatos de um passado que, apesar de vívido na sua memória, só se construiu a partir das histórias contadas e recontadas inúmeras vezes pelos seus pais. Ou seja, apoiada nas lembranças da memória coletiva, Elin faz referência ao seu local de origem, às adversidades do tempo no momento do embarque, entre outros detalhes da viagem.

[Recorte 10] Elin: Onde a gente morava hoje pertence à Lituânia, não é mais da Alemanha. Lá, o inverno é mais rigoroso, porque nós embarcamos parece que... \# não sei se foi em fevereiro que saímos de lá \# então, estava congelado o porto, o navio não pôde sair. Aí fomos de trem, acho que até Hamburgo, não me lembro porque era muito pequena \#\# não sei direito como é que foi... \# minha mãe contava... nós embarcamos e a bagagem ficou no navio lá em Memel, lá na fronteira 
da Lituânia com a Alemanha... Minha mãe contava essas histórias, de como foi sofrida a nossa vinda.

\subsubsection{A viagem}

A viagem da Alemanha até o Brasil ficou registrada na memória dos participantes como um fato marcante. Em todas as lembranças evocadas, as dificuldades são salientadas. Financiada pelas próprias famílias que à época detinham poucos recursos, os imigrantes não podiam almejar nada além da terceira classe no navio, conforme relata Thora.

[Recorte 11] Thora: Não era navio só de transportes, tinha outros também \# tinha até primeira classe, segunda classe e terceira. Nós viemos na terceira classe, né? E era de transporte também, ele parou em todos os portos para vender e comprar \# aí a gente podia sair do navio para passear.

Thora, participante de $1^{\mathrm{a}}$. geração, à época com dez anos de idade e hoje com 94, reporta fatos relativos à viagem que compõem a trajetória de sua família e que se juntam a outras vozes de uma mesma história que se repete para todos que se lançaram nessa empreitada imigratória. Grieger ${ }^{6}$ (1924 apud BRITO 2002a, p. 165), um imigrante alemão que registrou na forma de diário sua viagem da Alemanha para o Brasil relata:

[Recorte 12] "O navio divide-se em três classes, conforme as finanças de cada um. Na primeira classe, come-se muito bem e a terceira até se esquecem de servir. A maioria de nós é plebeu, e o dinheiro está [estava] em falta."

${ }^{6}$ GRIEGER, F. A viagem ao Brasil. Tradução de Edith Ludwig. 1924. Mimeografado. 
O relato de Grieger contém fatos que se misturam àqueles vividos e narrados pelos participantes deste estudo, e que dão forma e vida à memória de cada um em particular por meio de uma memória que é de todos. São esses e outros fatos que constituem a memória coletiva do grupo.

No recorte a seguir, Annie, como Thora, se vale da memória de sua mãe para relembrar detalhes da vinda para o Brasil. Ao evocar o passado, suas memórias reportam fatos não necessariamente presenciados, mas que foram ao longo dos anos sendo incorporados à sua própria memória. Em outras palavras, as memórias de Annie e Thora se interceptam em algum ponto do passado com as memórias de suas respectivas mães, fundindo-se numa só para confirmar suas lembranças ou recobrir hiatos de suas histórias.

[Recorte 13] Annie: Nós viemos no [navio] Santarém, um brasileiro \# é nesse que nós viemos. Agora, quanto tempo, isso eu não sei, eu não lembro, eu era pequena. Eu só sei que nós viemos e eu não gostei, porque era só água e céu o que a gente via. E cada vez que vinham as ondas, minha mãe conta que eu queria ir para cima, aí veio uma onda e encheu e eu fiquei com medo. Minha mãe dizia que eu falei assim: "Não quero mais fazer um viagem dessa”. (Entrevista coletiva A-10, 07/04/ 2006)

Halbwachs (2004) sublinha que o indivíduo carrega consigo uma bagagem de lembranças históricas que pode ser ampliada por meio da conversação ou pela leitura, uma espécie de memória emprestada como ocorre com muitas lembranças de infância, que são baseadas na memória compartilhada com os pais durante aquele período. Assim, quando fazemos referência aos nossos primeiros anos de vida, muitas vezes confundimos o que se ouviu dizer dos outros - pais, avós, familiares e pessoas próximas - com as próprias lembranças.

A fala de Thora (recorte 5), que se apoia na memória coletiva, encontra eco nas lembranças de Scarlatt: 
[Recorte 14] Scarlatt: Lá na Ilha das Flores, a gente queria ir para o Sul \# onde já tinha muitos alemães, porque a gente num falava nada de português, então pra gente era mais fácil aí \#\# precisava de dinheiro para pagar tudo, as terras, mas a gente num tinha mais dinheiro, gastamos tudo na viagem. (Entrevista B-03, 06/05/ 1978)

Embora façam referência a situações distintas, as falas de Annie e Scarllet nos recortes 13 e 14 sugerem um movimento contínuo entre memória coletiva e memória individual. Como supõe Halbwachs (2004), a memória coletiva tem origem no conjunto das lembranças comuns aos indivíduos que compõem um determinado grupo. Contudo, as lembranças surgem individualmente, diferem umas das outras de acordo com a experiência de cada um, mas convergem naquelas imagens e representações que dão ao grupo uma identidade x e não y. Para Douek (2003, p. 29), são as lembranças presentes na memória coletiva que tornam possível a transmissão da tradição de geração em geração - "tradição e memória coletiva andam, portanto, de mãos dadas".

Como num mosaico que vai se (re)compondo, peça por peça, a trajetória dos participantes deste estudo vai sendo delineada nesse movimento entre memória coletiva e memória individual. Nos recortes 15 e 16, as falas de Peter e Heinrich registram suas percepções acerca do deslocamento até a Cidade de Goiás, dando continuidade às narrativas de Thora, Annie e Scarllet:

[Recorte 15] Peter: Quando eles vieram da Alemanha, eles vieram de navio; levaram muitos dias, mais de mês praticamente de navio. Aí chegou no Rio de Janeiro, pegaram trem de ferro até Ipameri \#\# mas foi muitos dias \# aí as coisas que tinham trazido da Alemanha não tinha jeito de vir tudo \# aí, para não passar fome, eles vendiam aquelas coisas da Alemanha, panelas, essas coisas assim, o povo interessava comprar, né? Porque era da Alemanha, aí eles vieram até- perto de Ipameri \# é a última estação de trem de ferro e de lá até Goiás Velho vieram de carro de boi. 
[Recorte 16] Heinrich: Então de lá fomos transportados em carro de boi, quer dizer, ajuda de carro de boi, porque a maioria foi a pé até Goiás, [...] vieram apenas três carros de boi, sendo um para comitiva, um para transportar o pessoal e outro para bagagem. E essa demorou foi \# parece que treze ou quatorze dias até Goiás [...].

\subsection{4 $\mathrm{E}$ as dificuldades continuaram...}

Sem condições de ir para o sul do país, conforme alguns almejavam (recorte 15), o grupo acolheu a oferta do governo de Goiás em conceder gratuitamente cerca de 10 a 50 hectares de terra por família, além da promessa de atender às necessidades imediatas dos imigrantes - construção de moradias, aquisição de sementes e instrumentos destinados à lavoura, assistência médica, alimentação etc. No entanto, as vantagens oferecidas não se concretizaram conforme o prometido, e as dificuldades se agravaram na Cidade de Goiás. Segundo Brito (1992) e Wascheck (1993), desde o início os imigrantes em Goiás foram vítimas de uma política imigratória equivocada e mal orientada. O núcleo colonial foi implantado em um uma região bastante isolada e inóspita, distante 50 quilômetros da cidade mais próxima, Goiás. Esse fato acarretou uma série de problemas para os colonos, pois como afirma o professor Fritz Köhler, ${ }^{7}$ a distância dos centros de consumo e falta de transporte adequado dificultavam o escoamento da produção.

[Recorte 17] Fritz Köhler: Também um outro erro [foi] a colocação \# a colocação de uma colônia deve ser perto de um centro de consumo, senão, o trabalho dos colonos que não tem como esgotar os seus produtos, este é um caso também de Goiás, da Colônia de Uvá, essa foi uma dificuldade [...] (Entrevista B-02, 01/05/1978)

\footnotetext{
${ }^{7}$ Entrevista concedida a Maria Helena de Brito em sua pesquisa de mestrado.
} 
[Recorte 18] Louis: Daqui a Goiás eram só três moradores, aí a gente tinha que pousar na estrada, atravessar rio cheio \# era a maior dificuldade (...) animal atolava até a barriga, a gente tinha que levar as cargas pra lá e chegava lá tudo era controlado, o primeiro preço que achasse podia entregar porque num achava mais não, tinha que entregar por aquele preço. (Entrevista A-02, 22/01/2006)

[Recorte 19] Thora: Eles vendiam porcos, engordavam porcos, levavam pra Goiás, lá não tinha, mas precisavam vender barato, né? O que tinha pra vender... Outros serravam tábuas \# levavam tábuas para Goiás \# muitos que não tinham outro recurso então catavam guariroba e levavam pra Goiás pra vender, tudo em cima dos animais. Muitos até iam a pé, nessas pedras tudo. Meu esposo ia sempre levar coisas pra vender a pé \# porque o animal era só pra carga. (Entrevista coletiva A-10, 07/04/2006)

Para aqueles que vinham de regiões urbanas como Berlim, enfrentar as adversidades do local - mata densa, animais selvagens, clima totalmente diferente, doenças etc. - foi uma experiência traumatizante, conforme relata Klauss.

[Recorte 20] Klauss: Não, realmente foi difícil, muito difícil. Você tá lá num local civilizado [Alemanha] e de repente cai num meio de uma selva daquela lá, sabe? O que tinha muito era peixe, água e mata. (Entrevista coletiva A07, 24/01/2006).

Segundo Brito (1992), o fato de que muitos não tinham inclinação para a agricultura ou não estavam habituados com o manejo da terra que encontraram na região, além de outros fatores - clima adverso, solo pedregoso, falta de recursos para combater as pragas, colheitas insatisfatórias - agravou a situação desoladora dos colonos, levando alguns a retornarem para a Alemanha ou a migrarem para outras regiões do Brasil. Além disso, havia as questões de saúde. A assistência médica 
prometida aos colonos também não se concretizou. Vítimas de várias doenças como tuberculose, verminoses, malária, leishmaniose, ${ }^{8}$ entre outras, os colonos eram obrigados a se dirigirem à Cidade de Goiás, muitas vezes carregando os doentes em redes, ou então morriam antes mesmo de alcançarem qualquer assistência médica.

[Recorte 21] Louis: Então foi terrível \#\# adoecia uma pessoa aqui tinha que carregar na rede daqui até Goiás. Nem! Nem gosto de lembrar esse tempo não \# foi difícil demais... (Entrevista A-02, 22/01/2006)

[Recorte 22] Heinz: Muitos adoeceram, faleceram, como o meu pai, por exemplo, \# faleceu de crupe [...]. (Entrevista A-03, 22/01/2006)

[Recorte 23] Edith: [...] meu irmão morreu de malária.

Ent.: Outras pessoas também?

Edith: Muitas morreram de malária, de leishmaniose $[\ldots]$.

[Recorte 24] Peter: [...] doenças demais \#\# eles custaram aclimatar aqui, morreram muitos e muitos alemães de malária, maleita, papai teve seis meses de maleita \# ele quase faleceu.

A memória coletiva que se evidencia na maioria dos recortes até aqui apresentados se coloca como uma corrente contínua de pensamento que retém do passado aquilo que ainda está vivo ou é capaz de viver na consciência do grupo, neste caso os momentos vividos na Colônia ou dos quais se ouviu falar ao longo da existência. E embora Thora, Heinz, Edith, Louis, Peter, Klauss e todos os outros tenham suas próprias histórias, onde estão registrados seus fatos pessoais, todos os participantes reportam fatos e eventos que têm um fundamento comum. A motivação para a emigração, as dificuldades enfrentadas durante a viagem da Alemanha até a Colônia do Rio Uvá, as

${ }^{8}$ Doença de pele conhecida também como ferida brava ou úlcera de Bauru. 
adversidades do local, as doenças são marcas inscritas na memória do grupo e que foram ganhando vida em suas narrativas, muitas vezes de forma intensa, com emoção, a exemplo de Thora que não raro narrava suas lembranças com lágrimas nos olhos; outras vezes, de forma impessoal, na condição de ouvinte, de quem não viveu os acontecimentos, mas que ouviu de seus pais ou outros membros da comunidade.

O fato é que, mesmo distante do passado, o indivíduo continua sofrendo suas influências, sobretudo quando se tratam de lembranças marcantes como as reportadas pelos participantes deste estudo. Pollak (1989) acredita que lembranças traumatizantes sobrevivem dezenas de anos, muitas vezes confinadas ao silêncio, outras vezes esperam o momento propício para ser expressas e transmitidas oralmente de geração em geração.

Até aqui procuramos reconstruir parte da história da Colônia do Rio Uvá com o propósito de dar visibilidade a um contexto de imigração singular, que diferentemente do que aconteceu em outras regiões, ficou relegado à própria sorte. Grosso modo, a falta de uma política imigratória consistente por parte do governo do Estado bem como as adversidades enfrentadas no local foram responsáveis pela dispersão da comunidade. Muitos morreram por falta de assistência, como ressaltam Heinz, Edith e Peter; outros retornaram para Alemanha porque não suportaram a falta de condições adequadas de vida; e outros migraram para outras regiões do Brasil ou localidades de Goiás. É nesse cenário que procuramos compreender o lugar da língua alemã hoje na comunidade.

\subsection{O lugar da língua na memória do grupo}

A situação inicial dos alemães na Colônia do Rio Uvá é peculiar porque mostra como a comunidade tornou-se à época da imigração uma espécie de "ilha linguística". ${ }^{9}$ O local onde foram assentados os

${ }^{9}$ Uma ilha linguística é uma comunidade linguística resultando da assimilação cultural impedida ou retarda. Constitui-se numa minoria linguística separada de sua área principal e cercada por uma sociedade majoritária de aspectos étnicos e linguísticos diferentes, da qual se isola, ou é isolada, por uma disposição sócio-psicológica a qual motiva a separação. 
imigrantes, com dificuldades de acesso e contato com outras regiões povoadas por brasileiros naquela época, impôs aos imigrantes uma situação de isolamento que proporcionou condições para que pudessem por algum tempo viver em um universo predominantemente germânico, embora estivessem dentro do cerrado goiano. Naquele tempo, conforme mostram os recortes, a língua alemã predominava em praticamente todos os domínios de uso, inclusive na escola.

[Recorte 25] Judith: Quando eu vim pra cá só tinha mato \# de Goiás para cá acho que só tinha dois moradores. [...] Muitos anos só se falava alemão \# era só alemão, depois um brasileiro entrou aí pra trabalhar, aí fomos aprendendo [português] depois. (Entrevista coletiva A-4, 22/01/2006)

[Recorte 26] Heinz: [...] até os dez anos de idade aqui num tinha brasileiros, era só alemão. Quando eu estava com dez anos de idade ainda tinha poucos brasileiros aqui \# eu aprendi a falar português na escola, com oito anos de idade. (Entrevista A-17, 24/06/2006)

[Recorte 27] Edith: Então, no começo nós aprendemos só alemão [na escola], o meu pai era o professor.

Aos poucos, à medida que "o continente ia invadindo a ilha", o alemão passou a ceder espaço para o português, não só pela necessidade de falar português, ilustrada nos recortes 28-30, mas também pela adoção de uma política linguística contrária à manutenção do alemão ao longo das gerações, como sugerem os recortes a seguir.

[Recorte 28] Edith: [...] depois o governo mandou uma professora brasileira, então teve que aprender tudo de novo \# em português [...] porque só se falava alemão \# nas casas, nas ruas... porque era uma colônia, era um povoado [...] só lá na extremidade tinha uns brasileiros, os autóctones, \# agora, lá, no núcleo era só de alemães. (Entrevista coletiva A-07, 24/01/2006) 
[Recorte 29] Peter: Os pais exigiam em casa falar só o alemão, mas depois que eles colocaram comércio, aí caiu mais o uso do alemão porque já tinha que falar mais português, porque eles atendiam no comércio dele. (Entrevista A-12, 09/04/2006)

[Recorte 30] Karl: Às vezes a gente falava as duas línguas de uma vez, estava junto com meu pai, ele perguntava o que outro queria saber e o que ele estava falando \# tinha que falar português com um e o alemão com outro \#\# aí falava as duas línguas duma vez. (Entrevista A18, 24/06/2006)

Spinassé (2008, p. 120) em seu estudo sobre o hunsrückisch (uma variedade da língua alemã) como fator histórico da relação entre Brasil e Alemanha observa que no sul do país a nacionalização também significou uma "quebra na estrutura e na tradição do sistema escolar", que à época acontecia por meio da língua étnica. Assim diz a autora:

A prática (consciente ou não) da manutenção da língua alemã entre os imigrantes e seus descendentes ainda era muito forte em 1937, quando Getúlio Vargas outorgou a nacionalização no Brasil. Era destacada a importância de se caracterizar uma nacionalidade brasileira, uma identidade nacional de brasileiro, e qualquer manifestação em língua estrangeira era proibida. $\mathrm{O}$ português tornou-se mais do que nunca, obrigatório nas escolas primárias, e a estrutura tradicional de isolamento foi duramente combatida. Isso contribuiu para que mais elementos do português entrassem no alemão falado nas colônias: alguns indivíduos evitavam o alemão, trazendo mais o português para dentro das comunidades.

Além disso, outros fatores contribuíram para o deslocamento do alemão na Colônia do Rio Uvá. Durante a $2^{a}$ Guerra Mundial, assim como em outras partes do Brasil e do mundo, os alemães, em Goiás, sofreram pressões tanto da população em geral quanto das autoridades locais (BRITO, 1992; WASCHECK, 1993) pelo fato de 
que os alemães indiscriminadamente passaram a ser associados ao nazismo e às suas práticas hediondas. Klauss e Peter recordam a onda de repressão aos alemães que vigorou em todo o Brasil durante a segunda guerra mundial.

[Recorte 31] Klauss: A repressão contra os alemães aqui [em Goiás] não foi tão violenta, mas ela existiu, é claro que existiu. O Brasil entrou em guerra contra a Alemanha, e então nós passamos a ser os inimigos - 'vocês, alemães, são inimigos'.

Na Colônia do Rio Uvá a repressão da qual falam Klauss e Peter se deu, sobretudo, na forma de apreensão de armas e confiscos de publicações na língua alemã, além de uma suposta proibição de falar a língua na região.

[Recorte 32] Peter: Alguns falavam que não podiam mais falar em alemão em casa e nem na cidade de Goiás \# e teve também a busca na casa dos alemães \# é verdade, eu ouvia eles falarem \# teve busca na casa dos alemães, revirando tudo, as cartas da Alemanha levaram todas, as cartas eram censuradas mesmo, toda carta que vinha da Alemanha era aberta e depois fechada \# para ver o que estava comunicando. Também tinha uns que eram contra os alemães, eles chamavam QuintaColuna, eles eram contra os alemães, as pessoas falavam isso \# falavam que os alemães tinham muitas armas guardadas, \# aí vieram para fazer esse levantamento. Eu sei porque eles vieram bater na porta do meu tio e carregaram o que queriam carregar, tudo quanto é coisa escrita em alemão, eles tiraram. Tomaram os livros em alemão \# tomaram muitos, tiraram tudo que puderam carregar. As cartas eles levaram também, levaram o armamento todinho que eles tinham, porque naquele tempo todos eles tinham uma espingarda para poder se livrar dos bichos, pra matar bicho na roça, essas coisas. 
Como se pode observar, ainda estão vívidos na memória de Peter fatos que a história registra, seja por meio da memória coletiva ou de sua própria. O confisco dos materiais impressos, o medo, a proibição do uso da língua alemã, o rótulo de "inimigos", constituemse em elementos de uma história que é ao mesmo tempo individual e coletiva. É individual porque é parte da memória de cada um em particular, e é também coletiva porque entrecruza com outras memórias em algum ponto da história.

Nos recortes 33 e 34, Elin e Heinz recordam que naquela época a língua alemã passou a ser um símbolo do nazismo, tendo sido banida na cidade, embora na Colônia continuasse sendo usada.

[Recorte 33] Elin: Durante a guerra, sabe como é... não podia falar língua estrangeira, porque o alemão de qualquer maneira era nazista \#\# se era alemão era nazista \# era classificado como nazista. Naturalmente, o regime do Hitler provocou muita antipatia e receio também, e antipatia para o próprio povo alemão, apesar do governo ser um e o povo outro. [...] Lá [na Colônia, durante a $2^{\text {a }}$ Guerra Mundial] não tinha vigilante nenhum, então se falava em alemão, só em alemão.

[Recorte 34] Heinz: Essa repressão que teve foi mais pra cidade, aqui na Colônia quase não tinha \# também quase não saía [da Colônia], por isso não tinha muita influência sobre nós aqui, mas se ouvia dizer que lá fora eles perseguiam os alemães.

As lembranças individuais de Elin e de Heinz fazem coro com as de Louis e de tantos outros, ao mesmo tempo refletindo e refratando a memória coletiva do grupo. São memórias (re)construídas a partir de fatos vividos e ouvidos, cuja força advém do conjunto das lembranças comuns e que apoiadas entre si compõem a história do grupo.

Como sugere Pollack (1989), a memória é um dos elementos de preservação da herança histórica de um grupo, pois, por mais estável que seja, nenhum grupo tem sua perenidade garantida enquanto que a 
memória pode sobreviver a seu desaparecimento. É nesse sentido que a língua alemã passou a ser uma língua herdada, e embora não usada ou pouco usada, ainda se faz presente na memória do grupo como parte de seu patrimônio cultural.

[Recorte 35] Louis: [a proibição] surgiu da guerra de 1939 que terminou em 46. Por causa desse problema que foi proibido conversar em alemão \# então foi abandonando... não podia falar... \# proibiu \# aí foi abandonando \# foi deixando de usar, deixando, foi até acabar... Às vezes o sujeito sabe, mas... Essa vizinha aqui, Dona Stela, que tem uma sorveteria aí, ela nega saber [falar alemão], mas sabe \# tem muita gente que fala, mas nega, ficou uma marca pesada, né? Muita gente fala, mas nega... Então, para não se envolver em nada, nega [risos], é melhor para evitar atritos.

A discriminação, o medo, a insegurança, a hostilidade e o desconforto, conforme recordam Elin e Klaus, contribuíram para que o alemão fosse pouco a pouco deixando de ser usado para se tornar mais um elemento da memória do grupo.

[Recorte 36] Ent.: Os filhos da senhora não falam alemão? Elin: Falam um pouco, dá pra entender um pouquinho, mas falar assim, não falam não. A Patrícia, a que mora aqui [em Goiânia], ela fala um pouco mais \# a gente conversava um pouco, porque primeiro era pra conversar porque era mais uma língua, mas por causa da vizinhança a gente deixou de falar \# porque sempre criava atrito, é nazista, né? \# de certo modo era uma discriminação, mas tudo passa, né?

[Recorte 37] Klauss: Depois da guerra a gente ficou na mira de adversários, então a gente já ficava meio temeroso assim de falar em alemão, né? 
[Recorte 38] Klauss: Outra coisa, a gente num era bem visto, sabe? Depois dessa guerra aí, era a sensação que eu tinha na época, 'Ah, ele é alemão...' \# eu senti assim \# sentia que não era bem visto...

A imagem e o prestígio do grupo na sociedade são fatores importantes para a vitalidade de uma língua. Autores como Grosjean (1982), Romaine (1994), Baker (1997), entre outros, mostram que grupos minorizados que gozam de prestígio na sociedade majoritária têm mais chances de preservar a língua de origem do que aqueles que têm sua imagem, por exemplo, associada a algum fato sócio-histórico considerado negativo, como foi o caso dos participantes deste estudo. As atrocidades causadas pelo o nazismo, de grande repercussão em todo o mundo, geraram uma imagem ruim que passou a ser associada genericamente a todo e qualquer cidadão alemão, tornando-o, em consequência, objeto de depreciação. Falar a língua alemã em público passou a ser uma forma de denunciar uma imagem da qual os teutobrasileiros da Cidade de Goiás queriam (ou era preciso) se dissociar. Em outros termos, a ideologia racista nazista levou os imigrantes da Colônia do Rio Uvá a se sentirem ameaçados, "incomodados" em usar a língua alemã, e acabaram por sufocá-la, confiná-la a domínios restritos de uso até abandoná-la quase que completamente.

Muito pertinente ao contexto em tela é a observação de Engholm (1965, p 15) ${ }^{10}$ - "A língua é a chave para o coração de um povo. Se perdemos a chave, perdemos o povo “ (tradução nossa) - pois expressa o sentimento de perda do qual falam Heinz e Peter nos recortes 39 e 40 respectivamente. Há certa melancolia na fala de ambos quando se referem ao alemão como uma língua morta:

10 "Language is the key to the heart of a people. If we lose the key, we lose the people" (EVA ENGHOLM, apud ADEGBIJA, E., The context of language planning in Africa: an illustration with Nigeria. In: PÜTZ, M. (Org.). Language contact language conflict. Amsterdam/Philadelphia: John Benjamins, 1994, p. 139). 
[Recorte 39] Heinz: Então, para evitar a perda assim duma hora para outra, a gente tem que usar \# a gente sente aquilo \# de ser alemão, mas aquilo vai morrendo aos pouquinhos, pouquinhos..., a gente pensa que não vai morrer \# mas quando vê acabou, acabou... e a gente não sabe como...

Ent.: Então vocês sentem que a língua está morrendo com o passar desses anos?

Heinz: É \#\# ela já morreu, e também um pouco da gente... (Entrevista A-4, 22/01/2006)

[Recorte 40] Peter: [A língua alemã] até que tem importância \# só que a gente num continuou a usar ela mais... pior, a gente deveria ter usado ela mais com os filhos também, mas a gente foi muito sem \# sem fôlego \# num sei a palavra não \# agora é só na lembrança...de quando a gente falava lá na Colônia... (Entrevista A-19, 24/06/ 2006)

Retomando Pollak (1992), pode-se inferir que as lembranças de Heinz e Peter (e de todos os outros) acerca da língua alemã ou do tempo em que se falava o alemão na comunidade são elementos constituintes do sentimento de identidade e lealdade à cultura nacional alemã. Esse sentimento de germanidade é expresso por Heinz com emoção e palavras fortes quando afirma que a língua alemã já morreu e com ela "também um pouco da gente", isto é, uma parte de si, de uma imagem que construíram como "povo alemão". Peter, de modo semelhante, não encontra palavras para lamentar o fato de que a língua "agora é só na lembrança... de quando a gente falava lá na Colônia..."

Por outro lado, são essas lembranças que ainda hoje mantêm a história e a imagem do grupo como "os alemães da Colônia do Rio Uvá". Embora em desuso, a língua alemã é parte do discurso de pertencimento a um sistema de representação de uma cultura nacional, capaz de gerar sentimentos de identidade e lealdade à língua e à cultura alemã (HALL, 2006), marcados tanto nas falas de Peter e Heinz nos recortes anteriores quanto nas falas de Elin e Edith pela oposição "nós, os alemães" x "eles, os caipiras", quando se referem ao português rural aprendido na região: 
[Recorte 41] Elin: Lá na Colônia entre os alemães a gente conversava em alemão, e o português era dos caipiras, "nóis vai, nóis foi”, o português que nós aprendemos lá, quando pequenos, era esse, dos jeca-tatu, com os sertanejos [...], mas em casa era só o alemão e com eles a linguagem dos jeca-tatu. (Entrevista A-16, 23/06/ 2006)

[Recorte 42] Edith: Primeiro aprendemos o alemão em casa e depois a linguagem do jeca-tatu, a língua dos sertanejos [risos].

Elin: [risos] É a mistura de alemão com português [risos] (Entrevista coletiva A-07, 24/01/2006)

Tais representações parecem fazer jus à construção simbólica da "narrativa da nação" (Hall, 2006, p. 52), contada e recontada, neste caso, a partir de sentimentos, fatos e acontecimentos vividos ou ouvidos na comunidade. Com ênfase nas origens, a identidade nacional alemã parece estar lá adormecida na memória do grupo assim como a língua à espera de ser resgatada, como afirma Elin (recorte 43).

[Recorte 43] Annie: Isso [o sentimento de germanidade] vem no sangue, né? Eu mesma, por exemplo, tenho mais afinidade com o alemão, a língua, quer dizer, eu tenho amizade aqui, mas o meu coração, a minha alma, meu espírito, eu não sei, parece que é alemão. Eu puxo muito pro lado alemão.

[Recorte 44] Elin: Ela sempre prevalece [a língua alemã], por que você está com ela aqui dentro de você \# Ela fica guardada, precisando falar, eu falo. [...] (Entrevista A$16,23 / 06 / 2006)$

Já Peter parece ver a necessidade de se romper com o discurso de uma única cultura nacional em favor de representações híbridas onde várias são as possibilidades de combinação, lembrando que hoje sua língua dominante é o português por ser a mais usada em seu cotidiano (recorte 45). 
[Recorte 45] Peter: Na verdade, eu tenho sangue de alemão, mas a nacionalidade é brasileira, a língua agora é o português. Tem que ser assim, as duas coisas, para não dar confusão.

Esses recortes sugerem que os participantes deste estudo reconhecem a origem e a língua alemã como elementos de uma identidade nacional que ainda preservam por meio da memória que está sempre pronta para ser resgatada e assim dar continuidade à germanidade que dizem trazer dentro de si. Por outro lado, também se percebe na fala de Peter a compreensão de que as identidades culturais não são unificadas, mas ao contrário, hibridizadas a todo o momento pelas práticas sociais impostas tanto ao indivíduo quanto ao grupo. Essas representações estão refletidas na fala de Peter. Por um lado, "ter sangue alemão" é uma forma de marcar a etnia germânica ao passo que a nacionalidade brasileira é marcada pelo português que passou a ocupar o lugar da língua étnica. A solução para esse conflito parece ser simples para Peter - "Tem que ser assim, as duas coisas, para não dar confusão" - na medida em que busca na "mistura" (que não é genética, mas social) a ressignificação de suas identidades culturais.

\section{Considerações finais}

Buscamos neste estudo apresentar um recorte da história de um grupo de imigrantes oriundos de várias regiões da Alemanha que em 1924 se instalou às margens do Rio Uvá no cerrado goiano. Apoiados no conceito de memória de Halbwachs (2004), Pollak (1989) e Bosi (1994), entre outros, procuramos identificar o status da língua alemão nos dias de hoje na comunidade bem como os fatores que contribuíram para que essa língua tenha adquirido tal status.

A pesquisa etnográfica no local mostrou entre outras particularidades que a comunidade é hoje composta por pequenas propriedades rurais e está voltada para a pecuária e a agricultura de subsistência. A sua população é estimada em aproximadamente 300 pessoas, das quais apenas algumas são alemãs ou os seus descendentes, e os demais são brasileiros que pouco a pouco foram se estabelecendo na região. Essa redução no número dos imigrantes alemães se deu em 
razão, sobretudo, (i) do retorno precoce para a Alemanha ou deslocamento para outras partes do Brasil das famílias que não se adaptaram ao clima e à rudeza do local; (ii) do falecimento, ao longo dos anos, de grande parte dos alemães que lá se instalaram em razão das doenças e da dificuldade de acesso a centros desenvolvidos para buscar tratamento adequado; (iii) da falta de novos movimentos imigratórios que pudessem dar continuidade àquele ocorrido em 1924 e, assim, fortalecer a presença dos alemães na região; (iv) a necessidade de usar a língua portuguesa nas relações com a comunidade brasileira circundante.

A combinação desses fatores acabou provocando o deslocamento da língua alemã da condição de língua em uso nos anos iniciais da imigração para a condição de língua herdada, "adormecida" na memória dos remanescentes imigrantes que no passado constituíram a comunidade do Rio Uvá. É percebida como uma língua herdada porque, apesar de estar em desuso na comunidade, ainda se faz presente na memória coletiva do grupo como um elemento de identificação nacional, um traço de germanidade que os une à nação de origem e que marca a diferença entre "os civilizados" que falavam alemães e os sertanejos que falavam a língua dos “jeca-tatus”. É adormecida porque está em algum canto da memória desses indivíduos, podendo ser resgatada a qualquer momento para marcar uma identidade percebida como biológica - "que está no sangue" - , ainda que no plano do imaginário, conforme afirma Annie (recorte 43).

No que diz respeito ao uso da língua alemã ao longo do tempo, pode-se dizer que os participantes deste estudo passaram rapidamente, em menos de três gerações, de monolíngues em alemão à monolíngues em português. Todavia, o que chama a atenção neste caso é o fato de que o alemão, apesar de ter caído em desuso, mantém um status de língua étnica herdada e como tal tornou-se um elemento simbólico na construção de uma identidade nacional alemã imaginária que é sustentada pelas histórias que povoam o universo das memórias individuais e coletivas do grupo. São narrativas que ajudam a (re)construir uma imagem de povo alemão em terras inicialmente alheias, estrangeiras, mas que se "desestrangeirizam", pouco a pouco, para dar lugar a uma nova imagem, híbrida, ressiginificada. 


\section{Referências}

BAKER, C. Fundamentos de educación bilingue y bilinguismo. Madrid: Ediciones Cátedra, 1997.

BASTOS , C. Curso de direito constitucional. São Paulo: Saraiva, 1999.

BOLOGNINI, C. Z.; PAYER, M. O. Línguas de imigrantes. Revista Ciência e Cultura, São Paulo, a. 57, n. 2, 2005.

BOSI, E. Memória e sociedade: lembranças de velhos. São Paulo: Companhia das Letras, 1994.

BRITO, M. H. O. A Colônia Alemã do Uvá: uma tentativa de colonização em Goiás. Goiânia: CEGRAF/UFG, 1992.

BRITO, M. H. O. A viagem ao sertão: memória, cultura e imigração. Fragmentos da Cultura Goiana, v. 12 (especial), p. 161-170, 2002.

CRUZ, F. M. Uma perspectiva enunciativa das relações entre linguagem e memória no campo da neurolinguística. 2004. Dissertação (Mestrado em Linguística Aplicada) -Universidade Estadual de Campinas, Campinas.

DOUEK, S. S. Memória e exílio. São Paulo: Escuta, 2003.

EDEGBIJA, E. The context of language planning in Africa: an illustration with Nigéria. In: PUTZ, Martin. Language contact language conflict. Amsterdam/Philadelphia: John Benjamins, 1994. p. 139-164.

FREITAS, L. G. Conexão Jaraguá-Danbury: língua e identidade de imigrantes brasileiros nos Estados Unidos, 2003. Dissertação (Mestrado em Letras e Linguística) - Universidade Federal de Goiás. Goiânia.

GROSJEAN, F. Life with two languages: an introduction to bilingualism. Cambridge: Harvard University Press, 1982.

HALBWACHS, M. A memória coletiva. Trad. Lais Teles Benoir. São Paulo: Centauro, 2004. 
HALL, S. A identidade cultural na pós-modernidade. (Trad. Tomaz Tadeu da Silva e Guacira Lopes Louro), Rio de Janeiro: DP\&A, 1992.

KESSING, F. Antropologia cultural. Rio de Janeiro: Fundo da Cultura, 1972.

POIRIER, J.; CLAPIER-VALLADON, S.; RAYBAUT, P. Histórias de vida: teoria e prática. Oeiras, Portugal: Celta, 1999.

POLLAK, M. Memória, esquecimento, silêncio. Estudos Históricos, Rio de Janeiro, v. 2, n. 3, 1989. p. 3-15.

. Memória e identidade social. Estudos Históricos, Rio de Janeiro, v. 5, n. 10 , p. p. 200-212, 1992.

QUEIROZ, M. I. P. Relatos orais: do "indizível" ao "dizível". In: VON SIMSON, O. L. Experimentos com histórias de vida: Itália-Brasil. São Paulo: Vértice; Revista dos Tribunais, 1998.

RIBEIRO, D. O povo brasileiro: a formação e o sentido brasileiro. São Paulo: Companhia das Letras, 2006.

ROMAINE, S. Language in society: an introduction to Sociolinguistics. Oxford: Oxford University Press, 1994.

SPINASSÉ, K. P. O hunsrückisch no Brasil: a língua como fator histórico da relação entre Brasil e Alemanha. Espaço Plural, n. 19, p.117126, jul./dez. 2008.

THOMPSON, P. A voz do passado: história oral. Rio de Janeiro: Paz e Terra, 1992.

WARNIER, J. P. A mundialização da cultura. (Trad. Viviane Ribeiro). Bauru: Edusc, 2000. 